\title{
SUSTANABILITY MARKETING MIX FOR FOREST PRODUCTS VALUE CHAINS
}

\begin{abstract}
Considering the growth in population, the need for wood consumption also increases. The rapid progress of science and technology doubles the wood consumption, which needs supply, and at a glance, mainly from the forests. Forests for many reasons have faced decrease in production despite this extreme needs for wood. Given the problems of indiscriminate harvesting of wood from the forest to be continued, strategies for sustainable supply of raw materials for forest products industries should be considered. In this study, to determine a reliable solution the analytic network process for decision making with benefits, opportunities, costs and risks is used. The preliminary results show that combined alternative strategies are more preferred to the other alternatives.
\end{abstract}

Keywords: forest, marketing, sustainability, value chain.

\section{Introduction}

In addition to products, place, price and promotion there are also other factors within forest product industries that have to be taken in concern. The following is based on not only the four Ps mentioned above but also a vital factor more. Stable supply of raw materials in the forest products value chain should be considered. Here the question is how the sustainability marketing mix strategy is transferred into action. The last $\mathrm{P}$ here is Purvey. In the forest industry, environmental and societal demands have been mostly oriented towards environmental performance. Demands and their change over time can generally be summarized in the following manner (Juslin \& Hansen 2002): 1970s - emissions to water and air, Mid 1980s - recycling, Late 1980s - chlorine bleaching, Early 1990s - forestry and forest management, Mid $1990 \mathrm{~s}$ - forest certification and ecolabeling and in the 21 st Century - global climate change and the role of forests. Even though it is not sure how environmental concerns and non-governmental pressure on the forest industry will develop in the future, it is obvious that environmental issues cannot be ignored in marketing planning. On the other hand, taking into account environmental issues should not disrupt the supply of value chain. The solution is complex and should be detailed and using a comprehensive way the best solution should be selected.

\section{Literature Review}

Product design constitutes an active interface between demand (consumers) and supply (manufacturers) (Baumann et al., 2002). The factors compose the green product purchase decision is not only the green product itself, which provides the primary core benefit to the consumer but also the other social benefits that the consumer perceives it would have such as being environmentally safe (D'Souza, et al, 2006). Astutie (2015) showed that the most influential marketing mix variable was price with the odd pricing as the best strategy to increase the purchasing decision of Malang apples consumers at Giant MOG. Oflac (2015) found the marketing mix decisions made by DHL Logistics affect both B2B and B2C customers' brand perceptions and enhance the brand equity of DHL Logistics. Tieguhong et al, (2015) investigated that how governance influences non-timber forest product value chains in Cameroon. They showed corruption in the permit system further creates high transaction costs, negative environmental impacts.

\section{Objectives}

The objective of this research was to evaluate and priorities forest value chain strategies using a suitable multi criteria decision-making approach. 


\section{Research Design/Methodology}

Five alternatives were defined for the supply of forest products value chain. These alternatives include development of wood culturing, use of non-wood raw materials, development of cellulosic materials recycling, forest management, reforestation, and the combination of all cases.

\section{Data/Model Analysis}

As shown in Fig (2) at first a top-level network was create, which consists of a cluster containing the goal node and a second cluster containing the four merit nodes: Benefits (B), Opportunities (O), Costs (C) and Risks (R). Outline of the methodology was shown in Fig (1).

\begin{tabular}{|c|}
\hline Understanding the decision problem in detail \\
\hline Control criteria and subcriteria \\
\hline setting of network cluster \\
\hline Connecting of control criterion according to dependence influence \\
\hline Connect ing of other elements according to dependence influence \\
\hline Constructing the supermatrix for each criterion \\
\hline Paired comparison within the clusters \\
\hline Paired comparison as they influence \\
\hline Computing the limit prior ities \\
\hline Weighting each idealized limitvector \\
\hline z \\
\hline Determining strategic criteriapriorities \\
\hline Performing sensitivity analysis
\end{tabular}

Fig. 1. Outline of the methodology

\section{Conclusions}

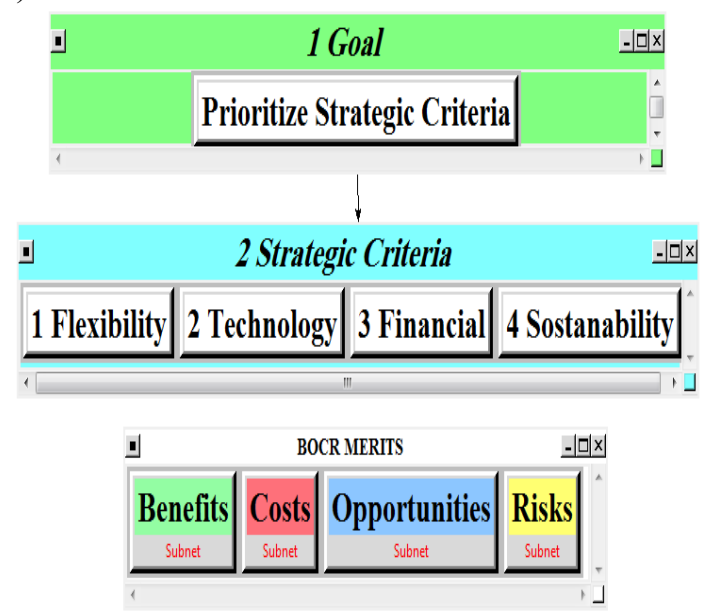

Fig. 2. The main model

Preliminary results showed that none of 1 to 4 alternatives (strategies) would not be able to supply all the needs of forest product industry. As a result, according to experts combination alternative (The fifth alternative) was introduced as the preferred option. This result means that the first four options are effective but not perfect strategy. The researchers will continue to follow the same order in which combination of options would be better.

\section{Key References}

Astuti, R, Lutfian, R, Silalahi, R, Dian, G, Wijaya, P, (2015). Marketing Strategy Based on Marketing Mix Influence on Purchasing Decisions of Malang Apples Consumers at Giant Olympic Garden Mall (MOG), Malang City, East Java Province, Indonesia, Agriculture and Agricultural Science Procedia, 3: 67-71.

Baumann, H., Boons, F. and Bragd, A. (2002), "Mapping the green product development field: engineering, policy and business perspectives", Journal of Cleaner Production, Vol. 10, pp. 409-25.

D'Souza, C., Taghian, M., Lamb, P., Peretiatkos, R., (2006), "Green products and corporate strategy: an empirical investigation", Society and Business Review, Vol. 1 Iss: 2, pp.144 - 157 .

Juslin, H. \& Hansen, E. (2002). Strategic Marketing in the Global Forest Industries. Authors Academic Press. Corvallis, Oregon. $607 \mathrm{p}$.

Oflac, B, Dobrucal, B, Yavas T, Escobar,M, (2015). Services Marketing Mix Efforts of a Global Services Brand: The Case of DHL Logistics., Procedia Economics and Finance, 23:1079-1083

Tieguhong J.C., Ingram V., Mala W.A., Ndoye O., Grouwels S. (2015). How governance impacts non-timber forest product value chains in Cameroon Forest Policy and Economics, 61: 1-10.

International Symposium of

the Analytic Hierarchy

Process 